\title{
Place Branding-The Challenges of Getting It Right: Coping with Success and Rebuilding from Crises
}

\author{
Heather Skinner (D)
}

check for

updates

Citation: Skinner, H. Place Branding-The Challenges of Getting It Right: Coping with Success and Rebuilding from Crises. Tour. Hosp. 2021, 2, 173-189. https://doi.org/ $10.3390 /$ tourhosp2010010

Academic Editors: Martin Thomas Falk, Miriam Scaglione, Alberto Amore, Bailey Ashton Adie and Brian Garrod

Received: 2 February 2021

Accepted: 13 March 2021

Published: 17 March 2021

Publisher's Note: MDPI stays neutral with regard to jurisdictional claims in published maps and institutional affiliations.

Copyright: (C) 2021 by the author. Licensee MDPI, Basel, Switzerland. This article is an open access article distributed under the terms and conditions of the Creative Commons Attribution (CC BY) license (https:// creativecommons.org/licenses/by/ $4.0 /)$.
Institute of Place Management, Manchester Metropolitan University, Manchester M15 6BH, UK; heatherskinnercorfu@gmail.com

\begin{abstract}
A focus on continued year-on-year economic growth was beginning to be seen as unsustainable even before the COVID-19 crisis forced many tourism destinations to rethink their marketing and branding. This paper adopts a critical marketing stance to explore the relationship between place branding and two recent extreme conditions affecting the tourism industry: overtourism, as exemplified when the issue became headline news in popular media from the summer of 2017, as many examples were offered of places struggling to cope with their success; and the COVID-19 crisis that effectively brought global tourism to a standstill in 2020, as the industry attempts to rebuild from this current unprecedented crisis. This article is not designed to suggest normative place-branding strategies. Rather, through the presentation of an original model that conceptualizes the cyclical process of rebuilding from crises and coping with success, it aims to provide a warning that whatever place-branding strategies are implemented in a post-pandemic world, for whatever type of tourism, in whatever type of destination, a rein must be employed in order that the drive for recovery from undertourism through successful place branding does not lead to the return of overtourism.
\end{abstract}

Keywords: COVID-19; crisis; undertourism; overtourism; tourismphobia; sustainability; destination branding

\section{Introduction}

Within only three years, both the study and practice of place branding have shifted dramatically from a focus on coping with success to focusing on how to rebuild from crisis [1]. Many places around the world were attracting ever-increasing and unsustainable numbers of tourists, so much so that the popular media were replete with examples of 2017's summer of overtourism [2]. By 2020, this situation had reversed drastically, with many popular destinations having to cope with little or no tourism, as the world all but ground to a standstill due to travel bans and restrictions brought about by the COVID-19 pandemic [3]. On one hand, this has led to certain calls to pause for thought and to consider what the tourism industry could, and even possibly should, look like in what is being termed the new normal [4]. On the other hand, the devastating economic impact of the pandemic has led to many places focusing on rebuilding tourism in order to get back to business as usual as quickly as possible [1].

Following a presentation of the critical marketing approach that underpins this work, the article first attempts to appropriately locate place branding within the practice of place marketing, considering the various approaches to the relationship between place marketing and place branding evident in the extant literature. This results in an original contribution to the literature in the form of a graphical representation of the five varying perspectives found in the extant literature (Figure 1). This is important in order to understand the rationale behind the role and purpose of place branding, and its relationship to other place-marketing and place-management initiatives. The paper then goes on to critique the way place branding is often used to achieve economic growth, especially through tourism development. Due to the criticisms of the practice and outcomes of place branding, the 
article also considers how it could be enacted in a more sustainable way, and in particular focuses on the concept of participatory place branding and stakeholder engagement. The media reporting of the summer of overtourism evidenced how strongly particularly resident stakeholders reacted to overtourism [2]. The COVID-19 pandemic affected global tourism very badly during 2020, and various different types of tourism destinations around the world are turning to place branding to recover from the problem of undertourism. The paper therefore explores the notion that, in doing so, some places could end up in a cycle of overtourism, to undertourism, and then back again.

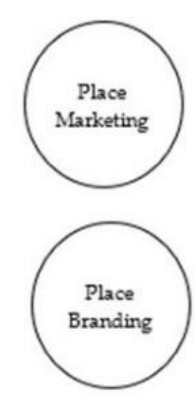

1

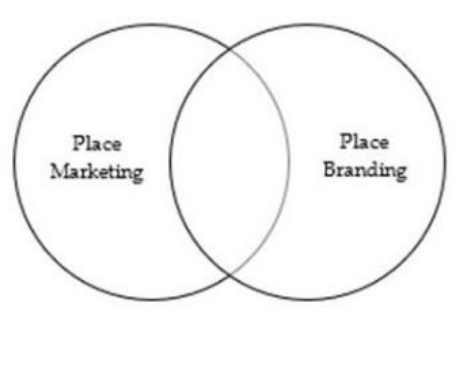

2

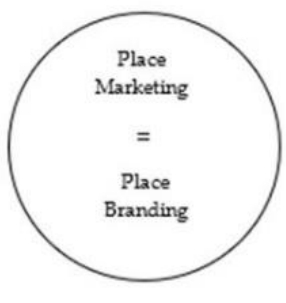

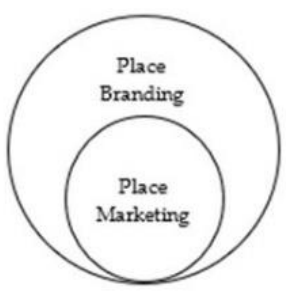

4

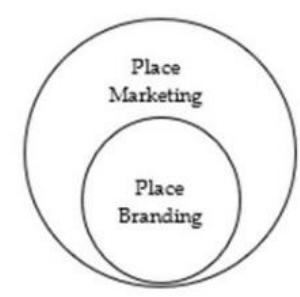

5

Figure 1. Various approaches to locating place marketing and place branding. (1) place marketing and place branding are separate and distinct constructs; (2) place marketing and place branding are separate constructs but can overlap; (3) place marketing = place branding; (4) lace marketing is part of place branding; (5) place branding is part of place marketing.

In this context, the aim of this paper is to provide a better understanding of the relationship between place branding and these two extremes-coping with the success that can lead to overtourism, and rebuilding from crises that can result in undertourism. In doing so, this article will also explore the key influences that impact on these issues, and the consequences they have. The result is the presentation of an original model that conceptualizes the cyclical process of rebuilding from crisis and coping with success (Figure 2). While in the context of this paper, the crisis in question is the recent COVID-19 pandemic, the model may be considered relevant to any tourism destination attempting to recover from any crisis through the use of place-branding strategies.

The rationale, and thus the timely and necessary consideration of the issues this paper covers, is the recognition that while COVID-19 may well have "spectacularly 'solved" the problem of overtourism "overnight ... it will come back, and places need to be more prepared than they have been in the past" [1] (p. 63).

This article therefore concludes that when it comes to the point that a place needs to rethink its branding strategy, whether in response to stakeholder pressure, or in response to a crisis or disaster, it should do so within a wider place-marketing and place-management context, as graphically represented by Figure 1, as this is likely to lead to the place adopting more sustainable and resilient branding strategies for the future, and not lead to cycles of either overtourism or undertourism, as graphically represented by Figure 2. 


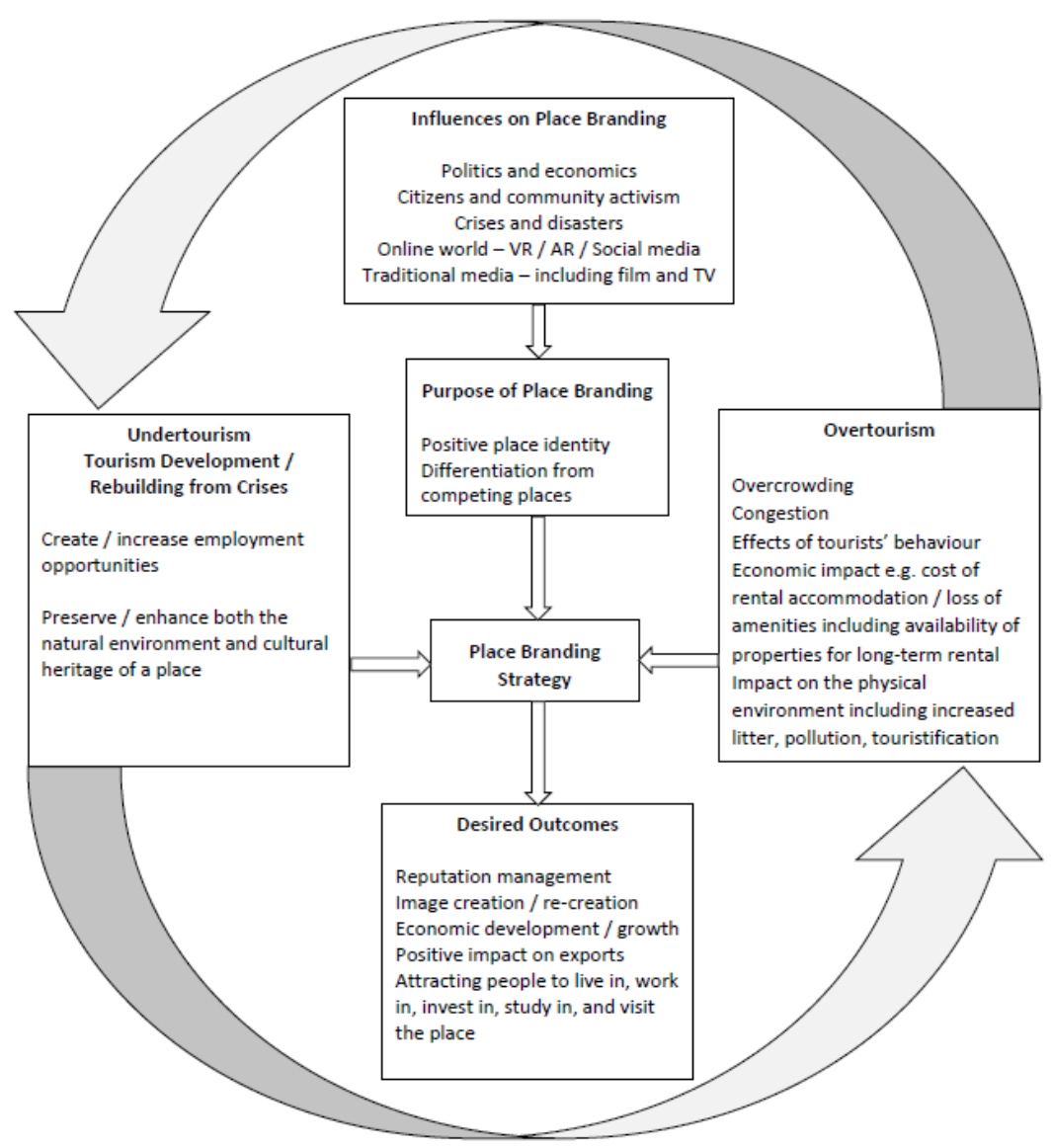

Figure 2. From undertourism to overtourism and back again: the cyclical process of rebuilding from crises and coping with success.

\section{Methodological Issues}

Since the concept of marketing was deemed to be broad enough to encompass the marketing of places [5], it has suffered a "crisis of representation" resulting in the proposition that there may be four alternative future directions that marketing could take: "retrenchment"; "realization"; "rearrangement"; and "reappraisal" [6]. This paper is not concerned with propositions for retrenchment, as it opposes the belief that marketing is not appropriate in some areas and is not universally applicable across all broadened horizons. This paper is more concerned with the direction of realization "that the marketing concept is basically sound, the problems lie in its implementation" [6] (p. 9). The position of reappraisal acknowledges "that the marketing concept has not succeeded and is unlikely to prove successful in its present form [because] selling has not, contra the marketing concept, been rendered redundant because few products actually sell themselves" [6] (p. 10). The other direction of "rearrangement", proposing that marketing should not focus so much on transactional issues such as customer satisfaction, rather it should focus on developing long-term relationships, is no longer seen to be inconsistent with the direction of realization. The approach of realization is also consistent with the critical marketing stance adopted in this paper.

The term "critical marketing" is often misunderstood; it is fluid and evolving, and its definition has led to "many controversial debates" [7] (p. xvii). A leading author in the field undertook research amongst the academic community and found definitions ranging from a view that critical marketing simply refers to interpretive or qualitative research; that the term is relevant to "larger social issues or using marketing for socially progressive purposes"; that it can be used only in a Marxist context; to the approach adopted by this paper-that critical marketing involves "being critical of more mainstream 
approaches to the study of markets and marketing" [8] (p. 4). For some, however, the term is perceived much more narrowly, and is seen to relate to only the "post-Marxist Critical Theory of the Frankfurt School" [7] (p. xx). Indeed, the term "critical marketing" itself could be seen to be somewhat of an oxymoron; however, the approach taken in this paper is that critical marketing involves being critical of marketing as a practice through "sceptical reflexivity" [7] (p. xx). This approach accepts its function, but highlights where improvements can be made to practice, particularly as this relates to addressing social injustice, rather than being critical of marketing as a discipline per se [8]. While some believe critical marketing is antimarketing, or is undertaken by postmodernists as "marketing anti-theory" [9] (p. 162), many others, including this author, adopt the view that it is more appropriate to perceive critical marketing as being essential to further our discipline, as it tends to challenge accepted wisdom [10]. Critical marketing from this perspective adopts a "pro marketing theory stance, but theory that adequately reflects the social, historical and political context in which marketing discourse and practice occurs" [10] (p. 727)

Thus, this paper embraces the pluralist perspective on the meaning of critical marketing [11]: it focuses on societal issues and processes (in this case, overtourism, crises, and place branding); addresses the issue of reflexivity in terms of how this work could be used to inform practice (through analysis of the way place branding is located within the extant literature, and through the analysis of real-world examples from practice); and finally, addresses the basic issues of marketing and consumption (through a critique of the practice of branding places and the construction of an original model that could help change not only the way we think about tourism and issues of sufficiency [4], but also the way we act [7] in order that we do not end up in a vicious cycle of undertourism to overtourism and back again). Issues of sustainability are also included in this paper, not only because "critique needs to bring about some type of change" to our thinking and our practices, but also because a consideration of sustainability in our marketing practices should challenge long-held assumptions about the purpose of marketing, its goals, and the actions we take in order to achieve our desired marketing outcomes [7] (p. xxi). This paper is conceptual rather than being framed as a systematic review, and as such does not present a state-of-the-art review of the literature; rather, it critiques the key themes relevant to the topics under investigation. Bearing in mind the highly interpretive and qualitative nature of critical marking research [8], and within its realm, the acceptance of "the role of the author in the construction of knowledge" [7] (p. xx), the concepts included within this paper have been purposively chosen. The choice of which issues to include has been undertaken unashamedly through the personal insights and knowledge the author has gained through over 20 years of undertaking academic research into marketing, and also through regularly undertaken practice-based consultancy, and is also consistent with the interpretive and critical approach undertaken in this paper.

Similar to a recent article on the cobranding of public place brands, and indeed touching on similar issues, the conceptual nature of this paper means there is no presentation of a "clear methodology" or "specific analytical tool" [12], yet it does contain real-world examples where it is appropriate to highlight the problems facing different types of places, and the various strategies they are employing to counteract these problems.

\section{Critical Review}

\subsection{Locating Place Branding}

Place branding is a growing and important area of practice and field of academic study. Interestingly, it is within a tourism context that the whole concept of place marketing was originally found to be most developed within the literature [13]. There also remains some confusion over where place branding is (or should be) located within the wider literature on place and place marketing that have been studied from many diverse disciplines [14,15]. Figure 1 represents an original conceptualization derived from an understanding of the various approaches to locating place marketing and place branding within the extant literature. 
The approach this paper adopts is the latter, that place branding is part of place marketing. This perspective also then locates place marketing within the wider discipline of place management, one that encompasses diverse strategies impacting on places, but which do not always have a market-getting focus $[15,16]$. The importance of adopting this perspective will be explored throughout the paper, especially as it impacts on issues of governance and stakeholder engagement.

\subsection{Purpose of Place Branding}

Branding may be quite succinctly encapsulated as having only two key facets, namely identification and distinctiveness. Branding makes something identifiable through naming and visual design, and makes it distinctive with meanings conveyed through the brand's personality and positioning [17]. Place branding can help differentiate one place competitively from another $[18,19]$ by creating and communicating a positive place identity aimed at attracting various target market segments [20] relevant to the type of place. At a national level, place branding is deemed to be necessary to compete in the global marketplace [21], and due to the competitive nature of the global environment, places need to be marketed [22].

Place branding can help places with outdated images, places with negative reputations, or places that are less well known. Place branding can also help target appropriate audiences for a place's communications, and expand, correct, enhance, revitalize, improve, refine, or contextualize perceived images [23]. The idea is that if all of this works effectively, then the appropriate target markets will be attracted to the place, and the place will develop a competitive (and thus economic) advantage over other places. Place branding does indeed seem effective, given the increased competition amongst places [24]. When applied to nations, along with positively impacting on exports and direct investment, it attracts people to work and live in a place $[25,26]$. Place branding can be particularly effective in attracting tourism and can have a positive impact at the national level [27]. There also tends to be a dominance in the place-branding literature of the urban [28], possibly because when it comes to branding places to attract tourists, "city tourism is the fastest growing market segment in tourism" [29] (p. 144). However, place branding is also used by a range of coastal and rural places, areas of outstanding natural beauty, heritage sites, and sites of ecological biodiversity not only for tourism development, but also for more general local economic development [30]. The plethora of single-place-based studies in the extant literature also evidences the wide range and type of places employing place branding, although by their highly localized nature, these studies do not always necessarily lead to more general conceptualization or theorization.

In many places, the place brand is "heavily or exclusively biased towards tourism" [23], reflecting the role of place branding in improving the developing world's economies because "in the end, even if a country has nothing to sell people, they can always come and have a look at it" [23]. However, the literature does find that city brands tend to focus on external promotion much more as a means of attracting tourists and direct investment [31] than other desired place branding outcomes.

Possibly due at least in part to its application at a national and municipal level, place branding is therefore seen as a public practice, usually undertaken by public-sector, localauthority bodies [31]. When undertaken in a tourism context the practice of place branding, then referred to as destination branding (with the place's marketing then referred to as destination marketing [14]), is usually charged to a destination management/marketing organization (DMO).

To clarify between place brand identity and place brand image, it is generally held in the literature that place brand managers create the place brand identity, that reflects the essence of what a place is, the genius loci or spirit of places [32]. This identity is created and communicated from the inside-out to its desired target audiences, who will develop their own perceptions of the place brand image from the outside-in [15]. However, the role of the DMO in creating and communicating a coherent place brand identity in an 
age of tourists' image sharing on social media has led to questions concerning the DMO's level of control over place brand creation and communication [33]. Moreover, it has been argued that it is the place brand image that comes first, and that place branding concerns the activities undertaken to alter the image as required [22]. Indeed, in a tourism context, people visit destinations because of the image they have of them [24].

How such images are perceived for destinations that are experiencing overtourism, or destinations that are perceived as unsafe for travel due to crises or disasters, and the problems that may arise when the place brand image does not match the place brand identity will be explored in more detail later in this paper. For now, the purpose and desired outcomes of place branding are summarized in Table 1.

Table 1. Purpose and desired outcomes of place branding.

\begin{tabular}{ccc}
\hline Place Brand Management & Purpose & Desired Outcomes \\
\hline & Positive place identity & $\begin{array}{c}\text { Reputation management, and image } \\
\text { creation/re-creation }\end{array}$ \\
\cline { 2 - 3 } $\begin{array}{c}\text { Place branding is a public practice most } \\
\text { usually undertaken by } \\
\text { governments/DMOs }\end{array}$ & $\begin{array}{c}\text { Differentiation from } \\
\text { competing places }\end{array}$ & $\begin{array}{c}\text { Economic development and growth } \\
\text { nation's exports }\end{array}$ \\
\cline { 2 - 3 } & & $\begin{array}{c}\text { Attracting people to live in, work in, } \\
\text { invest in, and visit the place }\end{array}$ \\
\hline
\end{tabular}

\subsection{Place Branding, Growth through Tourism Development, and Future Directions towards Sustainability}

Tourism development can have many positive impacts on a place. It creates jobs, both directly and indirectly [34]. If undertaken in a sustainable manner, tourism can help the preservation, and even enhancement of the natural and cultural heritage of a place [35]. Another positive impact can be seen in the area of voluntourism, which engages travelers with community projects in the places they visit [36]. Virtual reality (VR) and augmented reality (AR) technology can allow for a more enriched tourist experience of a destination, increase a destination's accessibility, and remove travel barriers in terms of distance, cost, or perceptions of danger [37]. As well as helping alleviate the problem of overtourism, virtual tours of places were instigated by tourism destinations and also by many museums and places of interest during 2020 when travel was restricted or banned due to COVID19. Thus, VR has shifted somewhat from a tool for tourism enhancement to a "travel substitution tool" [38] (p. 452). Hospitality and tourism service providers have found creative and innovative technologically based solutions to help address undertourism, some due to generally low visitor numbers, others in particular response to undertourism brought about due to COVID-19 travel restrictions, or people's safety concerns about travelling. When these solutions become promoted as part of the place brand, they may result in a more sustainable form of tourism in general. For example, virtual museum tours and virtual exhibitions have proved successful in not only combating a general decline in numbers of cultural tourists, but also in mitigating the impact of undertourism due to COVID-19 [39]. Indeed, it has been argued that if such online presence is managed effectively, it could actually benefit places through encouraging "the development of niche cities" [39] (p. 177). Similarly, calls have been made for governments of African nations to work jointly with private-sector tourism businesses to promote virtual or online tours of for "game parks, reserves and other tourist attractions in Africa" [40] (p. 1). Developing tourism this way, albeit as a recent reaction to COVID-19, also has the potential for more resilient and sustainable economic growth [40]. However, if VR is really to become a "travel substitution tool" in a post-pandemic world [38] (p. 452) and developed in a strategic manner that contributes to effectively managing and marketing a destination, it will be 
incumbent on "responsible authorities to come up with various technologies, laws and policies on property rights on the use of Internet so as to promote and protect use of virtual tourism" [40] (p. 10). Moreover, it will be incumbent on place marketers in all types of destinations to consider how appropriate the adoption of VR would be as a tool for sustainable tourism development, and not only those in urban environments, where much of the extant literature also focuses on "smart cities" at the expense of broader insights into how DMOs may harness technology in "poorer, rural, less-developed, or less technologically enabled destinations" on the wrong side of the "digital divide" [41] (p. 95).

Tourism development can also bring other benefits. Increase in tourism numbers can help improve a destination's infrastructure, which benefits the local community. Ecotourism and tourism that is nature-based can help promote and conserve wildlife and natural resources [34]. Effective place branding, as evidenced from rural Catalonia, can be undertaken in a bottom-up manner that can contribute to not only local economic development, but also in creating and communicating a "competitive territorial identity, the revaluation of endogenous local resources and the promotion of community-based rural development" [30] (p. 108). Moreover, residents in developing nations who may have previously relied upon farming or fishing, for example, could have access to alternative employment through tourism that may then also help reduce deforestation or overfishing [34].

Thus, even before the current pandemic affected tourism revenues across the world, growth remained a key strategic focus for many tourism destinations. Even destinations suffering from overtourism continued to set targets for increased numbers of visitors year-on-year. It has been proposed that all destinations want to win and to improve their fortunes [42], but this usually takes the concept of improving and winning from the perspective of better economic performance, rather than any other performance metrics. Even quality of life tends to be linked to economic improvement and is thus based on growth in economic terms only. Economic growth therefore becomes the required mandate of all those charged with the strategic management, marketing, and branding of places. There is emerging literature responding to the call to better understand the relationship between place branding and sustainability. A recent study found that while some places around the world were placing sustainability central to their brand positioning, most of these places focused mainly on its environmental aspect at the expense of the other two dimensions, economic and social, that form the "triple bottom line" of sustainability [43]. That article proposes 11 prominent dimensions in place sustainability: the natural environment, economic growth, social equity, built environment, landscape, liveability and health, conviviality, transport, energy, water and waste management, and governance. Each of these dimensions is then able to be evaluated by local government in order to provide an holistic analysis of their place, and therefore the specific dimensions that need to be addressed in the brand position in order to help develop the place sustainably [43].

While economic growth is often focused on tourism development, this can be a doubleedged sword. On one hand, the benefits and positive aspects of tourism are welcomed by many, yet the downside of uncontrolled tourism development can offer many negative impacts on a community. In a study of the small rural village of Hólar in Iceland, residents views could be seen to be polarized: while certain residents perceived increased numbers of tourists as a nuisance, others were concerned at the lack of tourist numbers to the village compared to the great increase in tourist numbers to the country as a whole. This paradox is summarized in the view of one resident who commented that, "We love their money but wish they would just send it and stay at home" [44].

Within this debate, there are also two separate constructs of sustainability and responsibility evident in the extant literature. In a tourism context, while individual ethics may guide the actions of those involved, social responsibility is "concerned with the impact of these actions on society and the environment" [45] (p. 173). Sustainable responsible tourism is therefore seen to involve a consideration of the conceptual impacts of sustainability (economic, sociocultural, and natural) along with the responsible implementation 
enablers, namely sustainability ethics, stakeholder cooperation/satisfaction, and visitor satisfaction [46]. However, what is not always considered is how tourism businesses themselves understand these concepts of sustainability, especially the small and medium sized tourism enterprises (SMTEs) that comprise by far the largest number of tourism businesses globally [45]. Moreover, the notion of responsible tourism as action implies responsibility, yet this also begs the question of who should be held responsible. Interestingly, "In many discussions on Responsible Tourism found in the extant literature, the onus of responsibility is placed more on the tourist consumer than the tourism business supplier" [45] (p. 173). Thus, in the context of overtourism and also in places that opened up to tourism during the pandemic, it is the tourist that is blamed for any problems arising, and the tourist against whom many resident and activist group protests were targeted in 2017. This appears to be happening again in social and popular media in 2020 where "travel shaming" is occurring. For example, there have been incidents in the UK when people photographed engaging in permissible and appropriately distanced domestic tourism activities received negative attention from police and also other citizens [47].

\subsection{Criticisms of Place Branding}

Place branding is usually "uncritically promoted in the literature as a 'force for

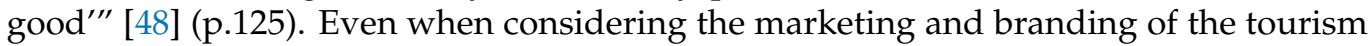
destination of Santorini, which had been highlighted in the media as suffering from overtourism, and the "aspects of the contested and dynamic processes and local particularities involved in the multifaceted reality" [49] (p. 142), there remained very little criticism of place branding as practice. However, the literature does reveal some criticisms levied at both the concept and the practice of place branding. Some authors have questioned the very relevance of the application of the branding concept to places [50]. Others note that place branding can generate "violent reactions" and "visceral antagonism" [51] (p. 24). At a national level, the links between nation brand and problematic issues associated with national identity and extremes of nationalism have also caused concern [52].

Place branding attracts criticism for being too much of a political activity, and one that can marginalize certain social groups, "causing social injustice and gentrification instead of bringing prosperity" [12] (p. 261). There are also published texts offering critical views on place branding, that identify many "unexplored consequences on the physical and social fabric of places" [53] (p.143).

The practice of place branding has also been criticized for being too heavily focused on economic success, raising questions about whether we should treat communities as markets, if we should be selling the city, and if we should judge successful places in purely economic terms [17].

When branding efforts are highly successful in attracting tourists to a destination, areas of outstanding natural beauty, heritage sites, and sites of ecological biodiversity can be destroyed by the very nature of attracting unsustainable numbers of tourists. While the UNWTO tends to see overtourism as an exclusively urban phenomenon [35], social media in the early summer of 2019 was flooded with images of queues of tourists heading up Mount Everest, where overtourism has led to increased littering, and even deaths of climbers due to the extended time it is now taking to reach the summit.

Many Mediterranean coastal destinations are being transformed into tourist-focused "strips" of large hotels (often transformed into all-inclusive resorts), bars, and restaurants that have no real relevance to the authenticity and heritage of the place in which they are located [54], and/or may be serving groups of tourists who behave irresponsibly, indulging in illegal and or risky behaviors such as excessive drinking, sexual activity, or drug-taking. In some cases, this aligns with the perceived brand image, for example 18-30 style holidays in places such as Kavos in Corfu, where the image is of a place where anything goes, and which is what attracts young people to the destination [55], yet which is at odds with the place brand identity communicated by Greece's National Tourism Organization [54]. 
City destinations that were highly successful had been facing protests from residents due to overcrowding, increased road traffic, limited facilities for everyone to use, rising housing costs for residents, environmental degradation, tourists' inappropriate behavior, and issues with Airbnb and cruise tourism [56].

"Visitor behaviour can have a detrimental effect on the quality of life of the host community. For example, crowding and congestion, drugs and alcohol problems, prostitution and increased crime levels can occur. Tourism can even infringe on human rights, with locals being displaced from their land to make way for new hotels or barred from beaches. Interaction with tourists can also lead to an erosion of traditional cultures and values" [34] (p. 200).

There can also be negative economic implications of some tourist developments. "Money generated by tourism does not always benefit the local community, as some of it leaks out to huge international companies, such as hotel chains. Destinations dependent on tourism can be adversely affected by events such as terrorism, natural disasters and economic recession" [34] (p. 200).

Residents who live in popular tourism destinations often do not want increased visitor numbers, and there have been many calls by citizens for "further protective action. They say they don't want the cities to lose their identities-the very identity that attracts tourists to the area in the first place" [57]. Criticisms are therefore levied at the way branding a place can commodify it, and "hijack" a place's culture [58] (p 98). Hence, place branding has been criticized for not fully engaging all place stakeholders [59]. This is important because lack of engagement with stakeholder groups, especially residents, can lead to tensions and a reluctance to accept and adopt the brand [31]. Although those charged with leading the branding of a place often claim they do engage place stakeholders sometimes resident engagement is undertaken only at a very superficial level with the place brand being imposed top-down rather than created in a bottom-up participatory manner [58].

\subsection{Participatory Place Branding and Stakeholder Engagement}

As a public practice driven by, sometimes managed by, and usually funded by government, whether at a national, regional, or more local level, place branding should involve meaningful stakeholder engagement as part of the place brand-creation process. Much of the literature in this area focuses on cities and the need to engage urban residents "as co-creators of the city brand" [31] (p. 230), rather than on other types of place brands and rural regions [30]. However, stakeholders of all types of places, especially residents of the place, are "vital to prosperous place brands" [58] (p. 97) and should be involved in participatory place branding [60-62], especially when there otherwise may be tensions between residents and visitors [63]. While other stakeholder groups, including urban planners, architects, local businesses, town and shopping center managers, retailers, and visitors are important [64], unless residents at a minimum accept, and at best take ownership [58] of the place brand, any place-branding strategy could be unsuccessful. However, "if done well, imaginative initiatives do not require much marketing at all as they will promote themselves in today's social media landscape" [17]. Yet when residents have rejected top-down place branding, they may also turn to social media "to chronicle their own place branding stories instead" [58] (p. 98).

The influence of the actions of all stakeholder groups on the place brand is very important. For example, place image can affect a business' site selection [25]. Attempts at achieving direct investment in a place can therefore be derailed if the image being perceived is at odds with the identity being projected.

The sheer proliferation and reach of social media cannot be ignored in this context. Consider the role of travel bloggers' influence on destination image and the tourist decision making process. These travel bloggers are seen as "social influencers in destination marketing" [65] (p. 245). Within this realm are two types of influencers: independent, who choose to blog in a private capacity; and sponsored, where the travel blogger is remunerated in some way in return for a blog about a destination, an attraction, or even tourist accommoda- 
tion. Here it is also important to understand the difference between the "projected online" destination image emanating from the $\mathrm{DMO}$, and the "perceived online" destination image that is shared by tourists [65] (p. 246). One recent study [65] found that the projected destination image focused more on diverse natural and cultural attractions, whereas the perceived destination image seemed to be more about the place under investigation, in this case the Philippines, as a cheap destination that offered fun and beautiful attractions. However, due to the way users share content across a range of social media platforms, it is becoming increasingly difficult to distinguish between content such as photographs, that originally emanate from sources such as government and DMOs, private-sector businesses, residents, and visitors [33]. Such evidence tends to suggest that we not only can but should recognize social media influencers' contributions to the brand-creation process whether these influencers are sponsored or independent, and thus they should be engaged in the participatory place-branding process. At the very least, government and DMOs should be actively scanning social media to find out who is saying what about their brand and what their audiences perceive about their brand, and to find out the extent to which the audience's perception is consistent with the identity that is being projected.

Another problem arising from not fully engaging all stakeholder groups is that branding efforts may work somewhat too well, resulting in popular tourism destinations attracting unsustainably high numbers of visitors, leading to what has been termed "overtourism".

Sometimes there can also be a mismatch between the brand identity a destination is trying to create and the destination image that is perceived, leading to the destination attracting a different target audience than hoped for-the "wrong type" of tourists-who may behave inappropriately in a destination, resulting in conflicts with local residents, a phenomenon that has led to the term "tourismphobia".

\subsection{From Overtourism and Tourismphobia, to Undertourism and Tourophobia ... and Back Again?}

Overtourism may be defined quite simply as "excessive visitation to a tourist destination" [66], yet the term overtourism does encompass three main issues: overcrowding in public spaces (and its impacts on the social environment); issues relating to tourists' behavior (such as increased noise, disturbance etc.) and impacts on the economic environment (including loss of amenities aimed at serving local residents as opposed to visitors); and changes (which are usually perceived as negative) to the physical environment (including the "physical touristification of city centers and other often-visited areas", and "increased waste, water use, air pollution") [67]. The term "tourismphobia" appeared for the first time in the El País newspaper in 2008 in an article titled "Turistofobia", written by the Catalan anthropologist Manuel Delgado. Delgado drew urgent attention to the emerging grassroots rejection of tourism and argued that the seemingly untrammeled growth of tourism posed a serious threat to Barcelona's social fabric [66].

As a result of overtourism and tourismphobia, an increasing number of critical residents' groups have been speaking up in an attempt to protect their everyday life and local practices, "reinforcing their agenda, both in the mass media and within local political arenas" [66]. The phenomenon of overtourism in cities forced government responses to counteract their local problems [68] and "to rethink their branding strategy" [69] (p. 3). Indeed, much of the literature on overtourism moved towards a focus on degrowth strategies $[66,68]$, and "the relation between tourism and its wider city context and the political aspects of excessive tourism growth" [67] (p. 4386). However, it is also stressed that overtourism must be dealt with in a wider place-management context that considers policy actions that more broadly address place usage, rather than simply addressing the problem in a tourism-management context [67]. This also aligns with the approach taken in this paper to locating place branding within place marketing, and place marketing within place management as discussed in relation to Figure 1.

The academic literature proposes that while place branding is not the only cause of overtourism it is definitely "is playing a significant role" in its emergence [69] (p. 1). A somewhat stronger position claims that overtourism is a "consequence of unregulated 
capital accumulation and growth strategies heavily associated with selling cities as tourism commodities" [66], which also aligns with some of the general criticisms of the concept and process of branding places discussed earlier in this paper [17,50,51].

Pressure evident in media reports for local government to do something to counteract the problems had been coming not only from activist groups of local residents and communities, but also from visitors themselves. This then was leading to the implementation of a range of destination-management strategies that focused on attempts to "spread visitors out in time and space, apply pricing strategies to match tourism supply and demand, regulate the accommodation supply, control Airbnb sharing and regulate overcrowding by limiting access to destinations or activities" [46] (p. 1828), along with strategies to manage the satisfaction of residents and visitors.

However, as many destinations were grappling with the problem of how to deal with overtourism, all sectors of the travel, tourism, and hospitality industries and their supply chains were affected quite suddenly by the unprecedented global COVID-19 crisis [55]. This has led to many places around the world having to grapple with the problem of undertourism, or indeed, no tourism at all $[3,70]$. Not only was global travel disrupted in 2020 by "health communication strategies and measures (e.g., social distancing, travel and mobility bans, community lockdowns, stay at home campaigns, self- or mandatoryquarantine, curbs on crowding)" [71], but even in 2021, there is an expectation that both international and domestic travel will restart to at least some extent, and there is evidence of potential travelers experiencing "tourophobia", a fear of travel that results from such a pandemic as COVID-19, but which has also affected potential travelers in the past as a result of other crises and disasters, whether natural or manmade [72]. Given the "seeming inevitability" of future crises and disasters, even a focus on tourism sustainability is giving way instead to an emerging focus on tourism resilience [73] (p. 14). Simply explained, whereas sustainability is concerned with preservation and conservation of resources, resilience is more concerned with reacting, responding, and adapting to change, with an emphasis being placed on capacity building towards recovery. However, the earlier literature has largely ignored "cultural, institutional or infrastructure resilience" [73] (p. 16), instead focusing more on the primacy of economic resilience. Yet, as can be seen from criticisms of the way place branding to increase tourism has tended to focus on economic growth, such focus can lead to responses that may not always result in benefits to tourism's host communities.

Not all destinations will recover at the same rate. City tourism has been particularly adversely affected by this pandemic, as urban centers were forced into lockdown [74]. Tourism activities that take place outdoors in the natural environment may also be evaluated more positively by travelers wishing to avoid close personal contact with others [71]. Domestic "staycations" may be more sustainable and resilient than international travel [75] and may help tourists overcome potential tourophobia that could accompany international travel. Indeed, in a post-pandemic world, the tourism agenda may well be more democratized across the world, reducing inequalities between indigenous host communities and global tourism service providers [76], and the tourism landscape may well become more inclusive, offering more opportunities for social justice, and less exploitation [4,74].

This current pandemic has had effects across all aspects of society, and these effects, such as measures to enforce physical distancing, are also being seen widely in public spaces as well as in tourism and hospitality service establishments. Innovative approaches have been taken across the industry to mitigate against the impact of COVID-19 regulations. Indeed, technology has played a central role in some of the innovative approaches to tourism service delivery, or for the provision of expanded tourism service delivery (such as virtual tours of attractions and destinations), as has been discussed earlier in thus paper. Thus, making destinations accessible despite safety concerns of travel bans [37,38]. The tourism industry is likely to be transformed at least technologically, as a result of COVID-19. For example, through the use of "mobility tracing apps, robotised-AI touchless service delivery, digital health passports and identity controls, social distancing and crowding 
control technologies, big data for fast and real time decision-making, humanoid robots delivering materials, disinfecting and sterilizing public spaces, detecting or measuring body temperature, providing safety or security" [71].

While the use of such technology may allow tourism to restart, there are two subsectors of the industry, involving "events and conference tourism dependent on mass gatherings [that] may take a long time to recover" [74]. It is yet to be seen if business tourism will ever fully recover, as almost all meetings, conferences, incentives, and events (MICE) have taken place virtually over the past year. Moreover, in a post-pandemic world, controlling the spread of COVID-19 will involve controlling the way people use places and outdoor spaces. It is likely that physical-distancing measures will continue well into the 2021 tourism season, and possibly even longer, similar to the way certain airport control measures that were introduced following the 2001 9/11 terrorist attacks in America remain in force today.

If previous place-branding efforts, especially those involving popular tourism destinations such as Santorini [49], were proving too successful to be sustainable, then perhaps the COVID-19 pandemic may provide the impetus to change focus somewhat. If a destination focuses solely, or even mainly, on attracting ever-increasing numbers of tourists to meet year-on-year growth targets, the evidence from 2017 onwards suggests that this will lead to problems for that destination to cope with the success of its place-branding efforts. Not only do tourists want to visit places that are good to be in, and safe to be in, but, regardless of any continuing requirements post-pandemic for physical distancing, place managers should consider how to make these places less overcrowded and consider how to make places that are good for workers, residents, and local communities, and where the local population are no longer suffering from or resenting the arrival of unsustainable numbers of visitors. However, evidence emerging out of the effects of COVID-19 on places in 2020 suggests that place managers should also focus on how such branding efforts could contribute to making places more resilient to future external crises and disasters for the benefit of all the place's stakeholders.

\subsection{The Cyclical Process of Rebuilding from Crises and Coping with Success}

Place-branding efforts with poor governance, or place-branding efforts that work too well and bring about great success and even lead to overtourism, are not always sustainable. As destinations attempt to recover from the undertourism brought about by COVID-19, a watchful eye must be kept on the success of any place-branding strategies in order for these also remain resilient to future disasters and crises, not least future overtourism crises. It is becoming acknowledged that "a place that is attractive and alluring to tourists should still be a place that is habitable and secure for local residents, and not sacrificed for the economic imperative above all else" [77] (p. 355). To counteract some of the problems arising from overtourism and tourismphobia, it has been recognized that there is a "need for alternative and more environment and host-friendly practices in development, planning, and policies" [78]. These strategies must also involve and incorporate the views of local residents [29]. However, caution must be taken that place-branding strategies to counter one problem do not lead to the other extreme, in which proactive strategies to counter overtourism do not lead to undertourism and vice versa. (Figure 2).

Perhaps rather than concentrating on increased global competitiveness and tourism growth, the future of place branding in the context of tourism destinations should focus more on sustainability. "Sustainable tourism development tries to establish a suitable balance between economic, environmental and social aspects of tourism development to guarantee its long-term sustainability" [29] (p. 146). Instead of a focus on growth as a tourism strategy, a clear and strong call has been made for destinations to focus on a sufficiency approach to the development of tourism [4]. There have been other calls for more of a focus on virtual tourism in which, through virtual reality (VR) technology, there is no requirement to travel in order to experience a destination [37-40].

The COVID-19 pandemic seems likely to affect global tourism well into 2021 and even beyond. It may be tempting for places to set higher tourism targets in 2021 to counter 
the economic impact felt by undertourism in 2020. However, place managers faced with these decisions should look closely at the effects of their previous place-branding strategies before doing so.

Some places around the world had used place-branding strategies to convince potential travelers their destination was safe to visit, especially developing countries relying on tourism revenues from the developed world to help their economies. The effect of the current pandemic is also expected to have an impact on health and safety concerns, and this may have a negative impact on such tourism revenues in the short-term as these places attempt to recover from this crisis. Continuing to attempt to attract large and ever-increasing visitor numbers may not even be possible. Perhaps in these cases, there should be much more selective targeting of relevant markets where a place's brand message, including one of safety, can be better communicated.

\section{Conclusions}

First, from a critical marketing perspective, because there still remains some confusion within the literature on place, it seemed important to locate place branding appropriately. While some approaches see place branding and place marketing as equivalent, separate, or overlapping, this article adopts the approach that place management is concerned with the overall management of the place and therefore includes, but is not limited to, efforts towards place marketing. Place marketing involves wider activities than branding, and therefore this paper locates place branding as just one place-marketing activity. Place management involves public funding, so place marketing and branding efforts therefore need good governance, and they should prioritize citizens over visitors, and should be held accountable for the consequences of their actions. The critical marketing approach adopted in this study of the relationship between place branding and the two extremes considered in this paper-coping with success that can lead to overtourism, and also rebuilding from crises that can result in undertourism - does not reject the concept that places can or should be branded. It does not reject the concept that places should seek to find ways to be economically viable in order to provide a good quality of life for all place users. Nor does this study take an anti-tourist, tourismphobic standpoint that seeks to drive away tourism from places. If critical marketing attempts at overcoming social injustice through marketing and consumption activities that are undertaken in an appropriate, responsible, ethical, and sustainable manner, it would be wrong to simply reject a whole industry that can bring so many benefits to so many different groups of place stakeholders, especially at a time of undertourism when the entire industry is attempting recovery from the impact of COVID-19.

While it may be tempting for places to seek to meet politically driven year-on-year tourism growth targets in terms of visitor numbers, such strategic focus can lead to overtourism that can cause dissatisfaction not only for a place's residents and investors, but also for the tourists themselves. Whereas, as destinations recover from this pandemic, a focus more on sufficiency of tourism numbers can lead to making places not only more sustainable and resilient to future disasters and crises, but also making them better for everyone, whether it is the place where they live, work, study, invest, or visit. The visitor experience is also likely to be better because their encounters are more likely to be with people who are pleased to see them rather than protesting about their very presence, especially given concerns about COVID-19 and overcrowded places, and telling them in no uncertain terms to go home and that they are not welcome. Lower tourism numbers that do not necessarily lead to a decrease in tourism revenues can be achieved by focusing more on higher-spending niche markets, rather than on lower-spending mass markets. For many destinations, especially those relying on seasonal visitors, a focus on niche markets rather than the core high season visitors can therefore also extend the destination's tourism season into the shoulder months, as many niche activities can take place outside of the core high season [54,79], so temporal crises do not necessarily take so much of a toll on the destination's economy. This can also help spread out the total number of a 
destination's visitors over a longer period of time during a year, decreasing overcrowding and congestion and also spreading tourist numbers and their expenditure over a wider geographical area around the destination's key must-see attractions or centers. Destinations can also capitalize much more on the commercialization of virtual tours to extend the season, albeit virtually [37-40]. Such a broader audience focus can also help make a place more sustainable and resilient because it is not targeting only one market segment. This can also then help a broader community base see evidence of the benefits of tourism, and thus be less resistant to its development or promotion. If effective place branding is in essence about competing against other places and winning, we should possibly consider how to play and win this global competitive game in a more sustainable and responsible manner. Then, winning the place-branding, place-marketing, and place-management game should involve being judged not on economic success factors alone, but also on success factors in the sociocultural and natural environment that contribute to quality of life. This then encompasses the three main conceptual impacts of sustainability along with the enabler seen to contribute to undertaking this in a responsible manner-ethics, stakeholder cooperation, and the satisfaction of both stakeholders and visitors.

The way place branding is managed in practice should be carefully critiqued more often than is currently evident in the extant literature, because there is evidence that when place branding is employed effectively it, can be so successful that it can lead to problems such as overtourism. In this respect, overtourism can be seen as a consequence of place branding. However, as illustrated by the examples offered throughout this article, in response to overtourism, places have to rethink their branding strategies. Hence, place branding becomes a consequence of overtourism. Many places had become victims of their own successful place-branding strategies by 2017, facing overtourism leading to overcrowding in public places; disruption to communities caused not only by the sheer number of visitors, but also by their sometimes antisocial behavior; the loss of amenities, especially affordable long-term accommodation rental; and touristification of the physical environment that prioritizes (or is perceived as prioritizing) visitors over residents. While these places are being judged as successful by their DMOs or governments, which happily promote their tourism growth figures, they would be judged as abject failures if evaluated in environmental and social terms. Sustainable place branding for the future should therefore focus not especially on growth but on sufficiency, focusing on attracting enough tourists, not necessarily more tourists.

We are yet in a position to establish the effect of place branding on recovery from this current pandemic, although the practice has been used to recover from the numerous previous disasters and crises that have affected places and their tourism industries. The concern at this point is that in an attempt to get back to business-as-usual as soon as possible, inappropriate place brand strategies could be employed that result in problems of coping with success in the future. We have seen many developing countries allow uncontrolled tourism developments as they start their tourism industries almost from scratch. Many countries in the developed world saw tourism reduced to almost nothing in 2020, with limited hope for full recovery in 2021. We should all take this opportunity to consider how we move forward with branding destinations for the future.

Funding: This research received no external funding.

Institutional Review Board Statement: Not applicable.

Informed Consent Statement: Not applicable.

Data Availability Statement: Not applicable.

Conflicts of Interest: The author declares no conflict of interest. 


\section{References}

1. Kavaratzis, M.; Florek, M. Editorial: Special Section-The future of place branding. Place Branding Public Dipl. 2021, 17, 63-64. [CrossRef]

2. Skift. Available online: https://skift.com/2017/08/16/summer-of-overtourism-4-lessons-for-the-travel-industry / (accessed on 24 November 2018).

3. Gössling, S.; Scott, D.; Hall, C.M. Pandemics, tourism and global change: A rapid assessment of COVID-19. J. Sustain. Tour. 2021, 29, 1-20. [CrossRef]

4. Higgins-Desbiolles, F. Sustainable tourism: Sustaining tourism or something more? Tour. Manag. Perspect. 2018, 25, 157-160. [CrossRef]

5. Kotler, P.; Levy, S.J. Broadening the Concept of Marketing. J. Mark. 1969, 33, 10-15. [CrossRef] [PubMed]

6. Brown, S. Life begins at 40? Further thoughts on marketing's mid-life crisis. Mark. Intell. Plan. 1995, 13, 4-17. [CrossRef]

7. Saren, M.; Maclaran, P.; Goulding, C.; Elliott, R.; Shankar, A.; Catterall, M. Introduction: Defining the Field of Critical Marketing. In Critical Marketing: Defining the Field; Saren, M., Maclaran, P., Goulding, C., Elliott, R., Shankar, A., Catterall, M., Eds.; Elsevier: Oxford, UK, 2007; pp. xvii-xxiii.

8. Scott, L.M. Critical Research in Marketing: An Armchair Report. In Critical Marketing: Defining the Field; Saren, M., Maclaran, P., Goulding, C., Elliott, R., Shankar, A., Catterall, M., Eds.; Elsevier: Oxford, UK, 2007; pp. 3-17.

9. Hetrick, W.P.; Lozada, H.R. Theory, ethical critique and the experience of marketing. In Rethinking Marketing; Brownlie, D., Saren, M., Wensley, R., Whittington, R., Eds.; Sage: London, UK, 1999.

10. Burton, D. Critical marketing theory: The blueprint? Eur. J. Mark. 2001, 35, 722-743. [CrossRef]

11. Schroeder, J. Critical Marketing: Insights for Informed Research and Teaching. In Critical Marketing: Defining the Field; Saren, M., Maclaran, P., Goulding, C., Elliott, R., Shankar, A., Catterall, M., Eds.; Elsevier: Oxford, UK, 2007; pp. 18-28.

12. Lucarelli, A. Co-branding public place brands: Towards an alternative approach to place branding. Place Branding Public Dipl. 2018, 14, 260-271. [CrossRef]

13. Hankinson, G. The brand images of tourism destinations: A study of the saliency of organic images. J. Prod. Brand Manag. 2004, 13, 6-14. [CrossRef]

14. Hanna, S.; Rowley, J. An analysis of terminology use in place branding. Place Branding Public Dipl. 2008, 4, 65-75. [CrossRef]

15. Skinner, H. The emergence and development of place marketing's confused identity. J. Mark. Manag. 2008, 24, 915-928. [CrossRef]

16. Parker, C. Extended editorial: Place-the trinal frontier. J. Place Manag. Dev. 2008, 1, 5-14. [CrossRef]

17. Govers, R. Editorial: Imaginative communities and place branding. Place Branding Public Dipl. 2020, 16, 1-5. [CrossRef]

18. Glińska, E.; Gorbaniuk, O. Restrictions on the use of the Aaker model in the measurement of city brand personality: The sender's perspective. Place Branding Public Dipl. 2016, 12, 46-58. [CrossRef]

19. Govers, R. From place marketing to place branding and back. Place Branding Public Dipl. 2011, 7, 227-231. [CrossRef]

20. Zenker, S.; Braun, E.; Petersen, S. Branding the destination versus the place: The effects of brand complexity and identification for residents and visitors. Tour. Manag. 2017, 58, 15-27. [CrossRef]

21. Anholt, S. Editorial: Nation brand as context and reputation. Place Branding 2004, 1, 224-228. [CrossRef]

22. Anholt, S. Editorial: Place branding: Is it marketing, or isn't it? Place Branding Public Dipl. 2008, 4, 1-6. [CrossRef]

23. Anholt, S. Editorial: Why brand? Some practical considerations for nation branding. Place Branding 2006, 2, 97-107. [CrossRef]

24. Kavaratzis, M. Place Branding: A Review of Trends and Conceptual Models. In Proceedings of the 38th Academy of Marketing Annual Conference, Dublin, Ireland, 5-7 July 2005.

25. Clouse, C.; Dixit, A.; Turken, N. The role of place image for business site selection: A research framework, propositions, and a case study. Place Branding Public Dipl. 2020, 16, 174-186. [CrossRef]

26. Kotler, P.; Asplund, C.; Rein, I.; Haider, D. Marketing Places Europe: How to Attract Investments, Industries, Residents and Visitors to Cities, Communities, Regions, and Nations in Europe; Pearson Education Ltd.: London, UK, 1999.

27. Superbrands. pp. 186-187. Available online: www.superbrands.com/turkeysb/trcopy/files/Anholt_3939.pdf (accessed on 15 January 2007).

28. Skinner, H. Representations of rural England in contemporary folk song. Arts Market. 2017, 7, 137-158. [CrossRef]

29. Postma, A.; Schmuecker, D. Understanding and overcoming negative impacts of tourism in city destinations: Conceptual model and strategic framework. J. Tour. Futures 2017, 3, 144-156. [CrossRef]

30. de San Eugenio-Vela, J.; Barniol-Carcasona, M. The relationship between rural branding and local development. A case study in the Catalonia's countryside: Territoris Serens (El Lluçanès). J. Rural. Stud. 2015, 37, 108-119. [CrossRef]

31. Casais, B.; Monteiro, P. Residents' involvement in city brand co-creation and their perceptions of city brand identity: A case study in Porto. Place Branding Public Dipl. 2019, 15, 229-237. [CrossRef]

32. Skinner, H. In search of the genius loci-the essence of a place brand. Mark. Rev. 2011, 11, 281-292. [CrossRef]

33. Skinner, $\mathrm{H}$. Who really creates the place brand? Considering the role of user generated content in creating and communicating a place identity. Commun. Soc. 2018, 31, 9-24.

34. Mandilas, A.; Dimitriadis, E.; Valsamidis, S. The perceptions of residents of a tourism site, for the economic impact of tourism in the area: The case of Samos Island. In Emerging Tourism Destinations: Working Towards Balanced Tourism Development, Proceedings of the 8th International Conference on Tourism, Kavala, Greece, 27-30 June 2018; International Association for Tourism Policy: Madrid, Spain, 2018. 
35. UNWTO. Available online: http:/ / www2.unwto.org/publication/european-union-tourism-trends (accessed on 7 November 2018).

36. Johnson and Wales University Scholars Archive. Available online: https://scholarsarchive.jwu.edu/cgi/viewcontent.cgi?referer= https: / / www.google.co.uk/\&httpsredir=1\&article=1027\&context=student_scholarship (accessed on 8 November 2018).

37. Giberson, J.; Griffin, T.; Dodds, R. Virtual Reality and Tourism: Will the Future of Travel be Virtual? In HTMResearch Working Paper No. 2017/1; Ryerson University: Toronto, ON, Canada, 2017.

38. Sarkady, D.; Neuburger, L.; Egger, R. Virtual Reality as a Travel Substitution Tool during COVID-19. In Information and Communication Technologies in Tourism 2021; Wörndl, W., Koo, C., Stienmetz, J.L., Eds.; Springer: Cham, Germany, 2021 ; pp. $452-463$.

39. Pascoal, S.; Tallone, L.; Furtado, M. The Impact of COVID-19 on Cultural Tourism: Virtual Exhibitions, Technology and Innovation. In Advances in Tourism, Technology and Systems. ICOTTS 2020. Smart Innovation, Systems and Technologies; Abreu, A., Liberato, D., González, E.A., Garcia Ojeda, J.C., Eds.; Springer: Singapore, 2021; Volume 209, pp. 177-185.

40. Chirisa, I.; Mutambisi, T.; Chivenge, M.; Mbasera, M.; Sidambe, M.; Muchenje, B.; Mukwashi, T.; Mabaso, E.; Ncube, R.; Zengeni, D. Scope for Virtual Tourism in the Times of COVID-19 in Select African Destinations. J. Soc. Sci. 2020, 64, 1-13. [CrossRef]

41. Skinner, H.; Sarpong, D.; White, G.R.T. Meeting the needs of the Millennials and Generation Z: Gamification in tourism through geocaching. J. Tour. Futures 2018, 4, 93-104. [CrossRef]

42. Audretsch, D.B. Everything in its Place: Entrepreneurship and the Strategic Management of Cities, Regions, and States; Oxford University Press: New York, NY, USA, 2015.

43. Taecharungroj, V.; Muthuta, M.; Boonchaiyapruek, P. Sustainability as a place brand position: A resident-centric analysis of the ten towns in the vicinity of Bangkok. Place Branding Public Dipl. 2019, 15, 210-228. [CrossRef]

44. Dewar, K.; Li Ra, W. Tourism in Hólar or not? The case of a reluctant rural destination. In Emerging Tourism Destinations: Working towards Balanced Tourism Development, Proceedings of the 8th International Conference on Tourism, Kavala, Greece, 27-30 June 2018; International Association for Tourism Policy: Madrid, Spain, 2018.

45. Skinner, $\mathrm{H}$. The impact of cultural values and economic constraints on tourism businesses' ethical practices. Int. J. Tour. Cities. 2019, 5, 169-187. [CrossRef]

46. Kuščer, K.; Mihalič, T. Residents' Attitudes towards Overtourism from the Perspective of Tourism Impacts and Cooperation: The Case of Ljubljana. Sustainability 2019, 11, 1823. [CrossRef]

47. Cresswell, T. Valuing mobility in a post COVID-19 world. Mobilities 2020. [CrossRef]

48. Mayes, R. A place in the sun: The politics of place, identity and branding. Place Branding Public Dipl. 2008, 4, 124-135. [CrossRef]

49. Lichrou, M.; O'Malley, L.; Patterson, M. Narratives of a tourism destination: Local particularities and their implications for place marketing and branding. Place Branding Public Dipl. 2010, 6, 134-144. [CrossRef]

50. Parkerson, B.; Saunders, J. City branding: Can goods and services branding models be used to brand cities? Place Branding 2005, 1, 242-264. [CrossRef]

51. Olins, W. Branding the nation-The historical context. J. Brand Manag. 2002, 9, 241-248. [CrossRef]

52. Skinner, H.; Kubacki, K. Unravelling the complex relationship between nationhood, national and cultural identity, and place branding. Place Branding Public Dipl. 2007, 3, 305-316. [CrossRef]

53. González, L.R. Book Review: Kavaratzis, M., Giovanardi, M., and Lichrou, M. (eds.), 2017, Inclusive place branding: Critical perspectives on theory and practice. Place Branding Public Dipl. 2019, 15, 143-144. [CrossRef]

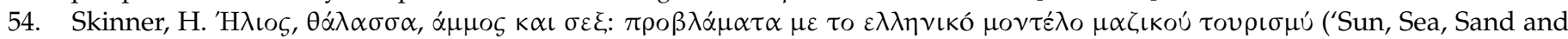

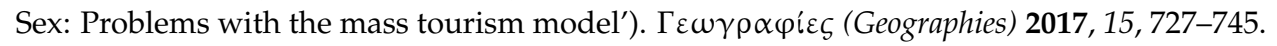

55. Williams-Burnett, N.; Skinner, H.; Fallon, J. Reality Television Portrayals of Tourists Behaving Badly. J. Travel Tour. Mark. 2016 35, 336-347.

56. UNWTO. Available online: http://publications.unwto.org/publication/overtourism-understanding-and-managing-urbantourism-growth-beyond-perceptions (accessed on 23 November 2018).

57. Reuters. Available online: https:/ / www.reuters.com/video/2017/08/05/overcrowding-at-europes-tourist-hotspots?videoId=37 2258898 (accessed on 24 November 2018).

58. Hudak, K.S. Resident stories and digital storytelling for participatory place branding. Place Branding Public Dipl. 2019, 15, 97-108. [CrossRef]

59. Brown, J. Attitudes and experiences of the rebranding of Liverpool: The Liverpool 08 local experience. In Proceedings of the Contemporary Issues in Retail Marketing Conference, Destinations and Locations: Exploring the Multiple Identities of Place, Manchester, UK, 9 September 2006.

60. Kavaratzis, M.; Kalandides, A. Rethinking the place brand: The interactive formation of place brands and the role of participatory place branding. Environ. Plan. A. 2015, 46, 1368-1382. [CrossRef]

61. Braun, E.; Kavaratzis, M.; Zenker, S. My city-my brand: The different roles of residents in place branding. J. Place Manag. Dev. 2013, 6, 18-28. [CrossRef]

62. Kavaratzis, M. From “necessary evil” to necessity: Stakeholders' involvement in place branding. J. Place Manag. Dev. 2012, 5, 7-19. [CrossRef]

63. Kavaratzis, M. The participatory place branding process for tourism: Linking visitors and residents through the city brand. In Tourism in the City; Springer: Berlin, Germany, 2017; pp. 93-107. 
64. Botschen, G.; Promberger, J.; Bernhart, J. Brand-driven identity development of places. J. Place Manag. Dev. 2017, 10, 152-172. [CrossRef]

65. Peralta, R.L. How vlogging promotes a destination image: A narrative analysis of popular travel vlogs about the Philippines. Place Branding Public Dipl. 2019, 15, 244-256. [CrossRef]

66. Milano, C.; Novelli, M.; Cheer, J.M. Overtourism and degrowth: A social movements perspective. J. Sustain. Tour. 2019, 27, 1857-1875. [CrossRef]

67. Koens, K.; Postma, A.; Papp, B. Is Overtourism Overused? Understanding the Impact of Tourism in a City Context. Sustainability 2018, 10, 4384. [CrossRef]

68. Lidija, 1. Solastalgia: An application in the overtourism context. Ann. Tour. Res. 2019, 82, 102766.

69. Séraphin, H.; Zaman, M.; Olver, S.; Bourliataux-Lajoinie, S.; Dosquet, F. Destination branding and overtourism. J. Hosp. Tour. Manag. 2019, 38, 1-4. [CrossRef]

70. Andriotis, K. Introduction. In Issues and Cases of Degrowth in Tourism; Andriotis, K., Ed.; CABI: Wellingford, CT, USA, 2021; pp. 1-21.

71. Sigala, M. Tourism and COVID-19: Impacts and implications for advancing and resetting industry and research. J. Bus. Res. 2020, 117, 312-321. [CrossRef]

72. Çakar, K. Tourophobia: Fear of travel resulting from man-made or natural disasters. Tour. Rev. 2020, 76. [CrossRef]

73. Lew, A.A. Scale, change and resilience in community tourism planning. Tour. Geogr. 2014, 16, 14-22. [CrossRef]

74. Ntounis, N.; Parker, C.; Skinner, H.; Steadman, C.; Warnaby, G. Tourism and Hospitality industry resilience during the Covid-19 pandemic: Evidence from England. Curr. Issues Tour. 2021. [CrossRef]

75. Prayag, G. Time for Reset? Covid-19 and Tourism Resilience. Tour. Rev. Int. 2020, 24, 79-184. [CrossRef]

76. Carr, A. COVID-19, indigenous peoples and tourism: A view from New Zealand. Tour. Geogr. 2020, 22, 491-502. [CrossRef]

77. Milano, C.; Novelli, M.; Cheer, J.M. Overtourism and Tourismphobia: A Journey Through Four Decades of Tourism Development, Planning and Local Concerns. Tour. Plan. Dev. 2019, 16, 353-357.

78. Saarinen, J. Traditions of sustainability in tourism studies. Ann. Tour. Res. 2006, 33, 1121-1140. [CrossRef]

79. Skinner, H.; Soomers, P. Spiritual tourism on the island of Corfu: Positive impacts of niche tourism versus the challenges of contested space. Int. J. Tour. Anthropol. 2019, 7, 21-39. [CrossRef] 